\title{
Frequency of Financial Reports
}

\author{
Javad Izadi Zadeh Darjezi ${ }^{1} \&$ Ehsan Khansalar $^{2}$ \\ ${ }^{1}$ Sussex Business School, University of Sussex, Brighton, UK \\ ${ }^{2}$ Kingston Business School, Kingston University London, London, UK \\ Correspondence: Javad Izadi Zadeh Darjezi, Sussex Business School, University of Sussex, Brighton, UK. \\ E-mail: J.Izadi@sussex.ac.uk
}

Received: May 22, 2013

Accepted: June 17, $2013 \quad$ Online Published: August 10, 2013

doi:10.5539/ijbm.v8n17p121

URL: http://dx.doi.org/10.5539/ijbm.v8n17p121

\begin{abstract}
Interim reports are summary statements that are usually prepared in semi-annual format in the UK. Until the EU's Transparency Directive was put into practice in the UK in 2007, there was no legal necessity for companies to provide interim financial reports. (Note 1) Instead such preparation was only a regulatory requirement of the London Stock Exchange. The responsibility on companies listed on the London Stock Exchange to provide these financial reports was first prepared as an suggestion in 1964, to meet the requirements for updates by financial analysts (May, 1971). In 1973, this advice to provide the market with interim information became a requirement for the admission of stocks and securities to be listed on the stock Exchange (Lunt, 1982). This study investigates the preparation of interim reports, and accounting standards for interim reporting. Also, this study discusses the main purpose of interim reports, the methods of preparation and the benefits of reporting frequency.
\end{abstract}

Keywords: interim report, interim information, reporting frequency

\section{Interim Reports and Accounting Standards}

In the UK, the first regulation on this topic from the regulator was Interim Reports (Accounting Standards Board, 1997). More recently, these guidelines have been replaced by a new statement entitled Half-yearly Financial Reports (Accounting Standards Board, 2007). For listed companies, however, the Financial Service Authority, applying the Transparency Directive, necessitates these companies to apply IAS 34, Interim Financial Reporting (International Accounting Standards Board, 1998, 2010). According to Deloitte (2010), the impact of IAS 34 is as follows (Note 2):

"IAS 34 'Interim Financial Reporting' prescribes the minimum content of an interim financial report. It outlines the recognition and measurement principles which are to be followed in interim financial statements."

Another feature of interim financial reports value highlighting at this stage is that they are not audited, which might be considered to influence their reliability for investment decision-making, although both Firth (1981) and Opong (1995) show that the UK market, as with the US market, comes into view to incorporate interim information into prices relatively quickly. Opong finds interim financial reports include information that is price sensitive and the effect of the related information happens on the day such statements are published.

Professional parameters for the preparation of interim reports have been in place in the USA since the 1970s, in the form of APB Opinion No. 28, Interim Financial Reporting (Accounting Principles Board, 1973). It is worth noting here that, whereas interim reports in the UK are provided half-yearly, this is dissimilar to the situation in the US where they are provided on a quarterly basis as required legally by the Securities and Exchange Commission. In fact, the SEC's founding agreement in 1934 gave it authority to necessitate financial interim reports, however, in the face of substantial opposition, although the requirement was first introduced in 1946, it was dropped in 1952, and then reintroduced over again in 1970 (Yee, 2004). Through the FASB, accounting standards in this respect were first developed as SFAS No. 3 Reporting Accounting Changes in Interim Financial Statements (Financial Accounting Standards Board, 1974) and further as SFAS No. 18 Financial Reporting for Segments of a Business Enterprise: Interim Financial Statements (Financial Accounting Standards Board, 1977). Under the authoritarian framework now in force in the USA, it is Regulation S-X and subsequent Financial Reporting Releases that set out the official requirements for interim financial statements as wanted under the securities legislation, with regular modifications between 1981 and 2011. (Note 3) 
In the UK, when the ASB first issued Interim Reports (Accounting Standards Board, 1997), the intention was to have influential power over best practice rather than mandatory force (it was not published correctly as an accounting standard because interim reporting was not required under the Companies Act). The ASB's 1997 statement suggested that interim financial reports should be drawn up by applying the similar principles and practices used for annual reporting, and that such statements should contain a narrative commentary and a summarised income, balance sheet and the cash flow statements, together with details of outstanding items, achievements and discontinued operations, and relative figures both for the matching interim financial period and for the previous full financial year.

In July 2007, the 1997 statement was re-titled Half-yearly Reports, having been updated and revised as a result of new disclosure and transparency regulations. It should be noted, however, this paper is concerned only with UK listed companies, and their interim reporting is now required to be in agreement with IFRS. (Note 4) The progress of an international standard started with disclosure draft E57 in 1997, leading to the publication of IAS 34 Interim Financial Reporting (International Accounting Standards Board, 1998), which became effective on 1 July 1999. A related IASB interpretation has been published since then, the IFRIC 10 Interim Financial Reporting and Impairment (Note 5) (International Accounting Standards Board, 2006), which became valuable for annual periods starting on or after November 1st 2006. Also, there have been two significant adjustments to IAS 34, one arising from the revision of IAS 1 in 2007, and the other arising from the Annual Improvements Programme in 2010. (Note 6)

Whilst IAS 34 identifies the content of an interim financial report conforming to International Financial Reporting Standards, it does not mandate which firms should issue interim financial statements, nor how regularly. The IASB leaves such substances up to stock exchanges, national governments, securities regulators and/or accounting standard setters. However, the Standard encourages interim financial reports, as a minimum for the first half of the fiscal year, to be made obtainable not later than 60 days and after the end of the interim period. (Note 7)

IAS 34 requires that the similar accounting policies should be used for interim reporting as are used in the firm's yearly reports. An example is for accounting policy modifies prepared after the time of the latest yearly financial reports that are to be replicated in the subsequent yearly financial reports (IAS 34.28). The important point is that a firm should use the similar accounting method during a financial year. If a result is made to change an accounting method mid-year, the change is employed all together, and until that time reported interim data is restated (IAS 34.43).

For interim reports purposes, the measurements should be prepared on a year-to-date basis therefore the frequency of the firm's reporting does not influence the measurement of its yearly outputs. The following thoughts are made explicit in this respect:

- Receiving revenues as seasonally in a financial period should not be predicted or postponed as of the interim date, if expectation or postponement would not be suitable at the year-end date(IAS 34.37);

- Expenditures that are incurred unequally through a financial year should be approximated or postponed for interim financial reporting reasons if it is suitable to estimate or postpone that kind of cost at the end of the full financial year (IAS 34.39);

- The expenses such as Tax should be distinguished according to the top estimate of the weighted average yearly effective rate of income tax which is anticipated for the financial year (IAS 34.B12). (Note 8)

- If the companies' trade is extremely seasonal, IAS 34 promotes to disclose the financial information for the most recent twelve months, and preparing comparable information for the previous twelve-month (IAS 34.21).

Although there is no officially requirement for auditors to reassess semi-annually reports before they are issued, managers can arrange for a review to be carried out as a separate commitment. Previously, the Auditing Practices Board Bulletin Review of Interim Financial Information (Auditing Practices Board Bulletin, 1999) set out direction for auditors on the processes to be undertaken when semi-annually reports re-examine. For accounting periods ending on or after $20^{\text {th }}$ September 2007, this is superseded by APB's adoption of the International Standard on Review Engagements (UK and Ireland) No. 2410, Review of Interim Financial Information Performed by the Independent Auditor of the Entity (Auditing Practices Board, 2007). This takes account of the changes to the detailed prerequisites on the issuing of the semi-annually reports by the UK listed firms for that reason of the EC Transparency Directive. Where the auditor's effort is done in harmony with the $\mathrm{ABP}$ regulation, the auditor's re-examine report should be issued in the semi-annually report. If the auditor carried out a range of the work less than that set out in the APB regulation, the managers should explain the information of the financial events in semi-annually report as 'neither audited nor reviewed'. 
The S-X Regulations in the USA also allow interim reports to be unaudited. It is worth noting here that they may be extremely condensed financial reports. For example, under SEC rules, interim income and balance sheets statements only need to include main captions (where data on components of inventories; finished goods, raw materials and work in process must be included either on the face of the balance sheet or in the notes to the financial statements). Where any main balance sheet statement caption is fewer than $10 \%$ of total assets and the total amount has not raised or declined by more than $25 \%$ given that the end of the previous financial year, the caption may be merged with the others.

Similarly, when any major profit and loss statement caption is fewer than $15 \%$ of average net income for the latest three financial years and the quantity has not increased or decreased about more than $20 \%$ as evaluated to the equivalent prior interim period, the caption may again be merged with others.

The cash flows statement may also be shortened, beginning with a form of net cash flows that comes from operating performance and changes in cash that rises from investing and financing activities when they become more than $10 \%$ of the average of net cash flows from operating activities for the latest three years.

These detailed regulations in the US demonstrate how firms can provide highly aggregated data in their interim financial statements, which, together with audit considerations, have given rise to a number of important research studies investigating the quality of interim financial statements, which is the background to the present study.

Brown and Pinello (2007) examine the usefulness of the financial reporting technique at restraining earnings surprise games. They argue that the yearly reporting procedure is subject to an independent audit while the interim reporting process is not. Also the annual reporting process has more precise expense recognition rules than the interim reporting procedure. It follows that annual reporting gives managers fewer opportunities to lead earnings upward. They argue that yearly reporting decreases the possibility of income-increasing in earnings by managers. However it increases the level of downward expectations for managers. Their results show that regulatory attempts to show corporations' internal checks and balances are probable to be more effective at restricting upward earnings management than at justifying negative surprise avoidance. (Note 9) The Brown and Pinello results shows that annual reports, unlike interim reports, are areas under discussion to independent audits and more inflexible expense detection rules. According to the interim financial reporting process, they demonstrate the annual reporting process decreases managers' tendency to manage earnings upward. Also, their findings show that managers bring into play downward expectations of management as an option method to make surprise earnings games when their capability to manage earnings upward is restricted.

Mangena and Tauringana (2007) examine the effectiveness of agency that related to the mechanisms on the level of disclosure compliance of interim reports with the ASB Statement. They show that in general disclosure compliance is not high and firms do not fully conform to the ASB Statement on interim financial reports. They use least square (OLS) as an ordinary model of regression to provide whether selected firm-specific and corporate governance qualities relate to the disclosure compliance degree. Their findings show that company range, multiple listing, dividend of interim period and new share issuance has a positive association with the degree of compliance. Furthermore, their result shows that the level of disclosure compliance is positively related with auditor participation, audit committee financial expertise and audit committee independence.

\section{Discussion}

According to Yee (2004), the quality of interim financial reports in the US, may suffer from the fact that, without final audit, material transactions such as business arrangements, restructuring provisions, major contracts and proceedings, may not be allocated accurately to the accounting period. This could emerge in the final period modifications when more focused audit procedures are performed on those events and transactions. Such modifications can cast suspicion on the integrity of the interim financial reporting, and cast a shadow over the reliability of interim financial statements. Furthermore, seasonality factors may create more volatile interim financial results, with revenues and costs in one particular period being shown as applicable to another period, and with uncertainties arising about costs that are not known until the end of the fiscal year. These issues may appear to be more sensitive under quarterly reporting in the USA, but it is notable that similar concerns are also increased with respect to semi-annual reporting, both in the UK (Opong, 1995; Mangena \& Pike, 2004; Mangena \& Tauringana, 2007) and more widely in the EU (Schiller \& Vegt, 2010).

Schiller and Vegt (2010) investigate the effect of interim financial reporting on the quality of accounting. They argued that management's preferred objective is a high stock price. They argue that managers in each sub-period may bias accounting reports Also, Schiller and Vegt argued that the enforcement structure ties sanctions to the detected gap between reported accounting earnings and net cash flows from firm activities at the liquidation 
stage. They argued that there are many a circumstance in which interim reporting does not improve accounting features. Their result indicated that biased reports in the short term stay on with lower incremental sanctions at each reporting period. They tried to find another clarification for the low accounting quality of interim financial reports. They tried to look at the strategic communication between investors and managers.

Schiller and Vegt show that interim reporting can improve the quality of accounting if there is stability with earnings-inflating financial reports and if the management favourite for having a high stock price is adequately low relation to the sanctions for distinguished misreporting. Also, they believe the reverse effects on accounting have a tendency to occur if these favourites are sufficiently high relation to the sanctions. They show biased interim reporting can even lead to trouble if the manager has no short-term favourite to get a high stock price. The finding has implications for discussion of management compensation. To protect reputations, managers will bias earnings in the short term even if there is no short-term motivation to do.

Yee (2004) presents four reasons in favour of interim reporting. First, he believes that improving the timeliness of disclosure helps investors to control and monitor the performance of managers and consequently reduces agency frictions. Second, if news can be incorporated more repeatedly in prices, this improves the capital allocation efficiency. Third, distribution news across interim earnings announcements shrinks information asymmetry between sophisticated and less sophisticated traders and users, which may improve market liquidity on the date of earnings announcement. Fourth, Interim financial reporting may reduce the interim information asymmetry between internal users and the public or external users, more frequent interim financial reporting may decrease the usefulness of rent-seeking efforts by analysts trying to get information that is not disclosed More specifically, by providing a suggestion of how the firm is improving during the annual reporting period, interim reports can aid financial analysts in predicting, at a minimum, the possible outcome for the year with respect to the variables of interest to them. That is, in providing an update on firms' activities to financial analysts in this way; interim reporting is capable of contributing to a reduction in insider trading by setting into the public domain timely information which would otherwise be confidentially held until the year end (Opong, 1995).

Mensah and Werner (2008) examined the extent to which the frequency of interim financial reporting may affect share price volatility in financial market over the course of the year. They examination focuses on different interim reporting regimes in four different countries: Canada and the United States with quarterly reporting, and Australia and the UK with half-yearly interim financial reporting. They argue in the trade-off between predictive value and timeliness of the interim reports, half-yearly interim financial reporting will guide to lower price volatility. These expectations are supported in their findings. Furthermore, further tests accomplished on American ADRs of Australian and British companies demonstrate that such firms have upper volatilities than similar domestic companies on their home stock exchanges.

Mensah and Werner argue that the alternative of interim reporting intervals might be a significant factor in obtaining greater competence in the capital markets for two motivations. First, more frequent interim financial reports can signal that security values show the most recent company-specific information, leading to more competent stock pricing. Secondly, more numerous interim financial reports can force companies to put together more estimates. Therefore, more informed estimates are obtainable only with the passing of time. However, the more frequent interim financial reports may be subject to more error. Therefore, investors reacting to the more frequent interim financial reports may affect bigger volatility in security prices.

The London Stock Exchange had included with its listing requirements the construction and allocation of interim financial statements at half-yearly intervals. In Great Britain accounting regulators formally accepted such interim reporting rules only in 1997. The Accounting Standards Board of the UK Statement on Interim Reports and their Statement on Preliminary Announcements (published in July 1998) presented voluntary 'best practice' guidelines aimed to complement the guidelines of the London Stock Exchange. Mensah and Werner's study provide that quarterly reporting highlights capital market volatility in the Canada and United States as compared to the capital markets in the UK and Australia.

An old argument against preparing more regular interim reports relates to the administrative expenses associated with compiling and allocating such reports, although by using new technologies, computer and the Internet have reduced the force of such arguments. Also, it is still not clear whether mandating more regular interim reports actually does increase overall disclosure. According to McNichols and Manegold (1983), interim reporting minimally provides information that would otherwise be disclosed in later annual reports. Indeed, Gigler and Hemmer (1998) show that mandating more regular interim reporting cause's managers to decrease their voluntary disclosure. 
According to Butler et al. (2002), in the United States, unlike the UK, there is evidence that the establishment of mandatory quarterly reporting did not increase earnings timeliness. The main reason is that quarterly reporting replaced appropriate voluntary disclosures by firms beyond the financial statements. This may even have undesirable side effects, as Butler et al. claim that forcing managers to report earnings more frequently may cause them to make unreasonable judgments, and dropping asymmetry information between competing companies throughout increasing the timeliness of disclosure can change the nature of competition in the market and may probable misrepresent productivity.

A further argument is that more frequent reporting may encourage additional information collection activity by users and financial analysts, with the increased expenditure on such activities being a social cost. For example, when Cuijpers and Peek (2010) examined how quarterly and semi-annual reporting affects investor information, they showed that a company's reporting frequency has no consequence on the precision of that information, on average. However, in spite of some of the reservations expressed above, their analysis of price variance in announcement periods provides counter-evidence that an increase in reporting frequency can make the information of financial reports more significant to users. That is, as investors in semi-annual reporters become visible to obtain more pre-announcement information than users in quarterly reporters, it may be construed that an increase in a company's reporting frequency decreases investors and users' incentives to acquire private information between consecutive declaration dates.

Recently, Doran (2011) shows that interim period earnings performance is related to year-end earnings performance. He measures earnings performance as the differences between reported earnings and forecasted earnings. He compares interim period and the year-end earnings performance by analysing two groups of firms. One of the groups contains firms with only interim future reports included in the earnings forecast; the other group includes firms where the forecast concludes at end of the fiscal year. The results show that the end of the fiscal year group has relatively critical earnings performance.

Pahlevan and Ranjbar (2011) examine the factors (company attributes, management and performance) affecting the timeliness of interim financial reporting in the listed companies of Malaysia. Their research considers transparency as a company's attributes, capital structure and the agency problem as characteristics of company's management. Also they consider growth, net gain, and profitability in the interim period as a measure of company performance. They focus on the Malaysia exchange market and choose the 30 largest and 70 mid-size companies that listed in the Malaysia stock exchange in 2007. After exclusion of banks, financial institutes, and companies with lack of data, the remaining list includes 72 companies. The fourth quarter of 2007 is considered as the basis of interim financial reports. According to their research these companies disclose their reports with on average a lag of 54 days. The official deadline for revelation of companies' quarterly reports is two months, therefore it is concluded that companies are inclined to disclose their reports with a delay.

\section{Implications for Research Design}

Dechow et al. (1998) argue that, whilst a shorter earnings measurement interval and a consequent increase in observations are the benefits that come from using interim data, short period data makes analytics and empirics more complicated by introducing considerable measurement error into the analysis. They also argue that seasonality in such data may require the analytics to be modified or the seasonality removed from the data prior to testing. The benefits, it seems, are more than offset by the difficulties of modelling and estimating the intra-year accounting process. In shorter periods, accruals are largely related to cash flows, which gives rise to greater differences in forecasts given the time-series properties of earnings, accruals and operating cash flows. In addition, there is evidence that the accrual process may fluctuate between interim reporting periods, i.e. quarterly in the US (Collins et al., 1984; Kross \& Schroeder, 1990; Salamon \& Stober, 1994; Rangan and Sloan, 1998), and that more temporary earnings items and losses are reported in the fourth quarter (Hayn \& Watts, 1997), consistent with an accounting process that concentrates on an annual horizon.

According to the GAAP each quarterly reporting period being considered as an integral part of the annual financial reporting period is consistent with evidence presented by Rangan and Sloan (1998) concerning the auto-regressive structure of seasonally differenced quarterly earnings. As the fiscal year improves, estimates are revised and estimation errors from earlier quarters are incorporated in earnings, as they are realised. As an example, merchandising firms, which are permitted to use the gross profit method to estimate cost of goods sold, appear to apply an estimated gross profit margin to reported quarterly sales to conclude quarterly cost of goods sold in the first three fiscal quarters, at the same time as inventory levels are audited to find out annual cost of goods sold to provide year-end financial statements. Taxes provide a second example of interim expense allocation. Firms calculate quarterly tax expense by estimating the effective tax rate for the full fiscal year and 
applying this rate to quarterly earnings, with the estimated effective tax rate than being updated.

These inferences are not new. In a relatively early study, Newell (1969) states that, since year-end adjustments have a considerable effect on the previous interim period (the fourth quarter in the US), revenue and other expense in the provided net income should often be affected. Newell's study demonstrates how interim data are exposed to many limitations, e.g. (a) how yearly fixed costs allocates to the interim periods; (b) how windfalls or miscellaneous revenues allocates to interim periods of; and (c) accounting for necessitated adjustments which are disclosed only at year-end. Moreover, as interim statements were then unaudited, Newell pointed out the opportunity for the company to provide financial reports that are not derived as an effect of principles acceptable to an independent public accountant, providing greater opportunities to 'manage' reported interim income than reported annual income.

Recent research in the UK echoes these considerations. Mangena and Tauringana (2008) investigate the relationship between audit committees and the decision to engage external auditors to reassess the interim financial reports that has already published. They use interim reports of 258 UK listed companies, and find that engaging an external auditor to review interim financial reports increases with audit committee independence and financial proficiency, concluding that such decisions can improve the quality of interim financial reporting.

\section{Conclusions}

This study has described interim accounting reporting in the UK, including professional instructions to prepare the interim reports, and related accounting standards for interim reporting. Also presented is a discussion of the main purpose of interim reports, the methods of preparation, the benefits of reviewing the reports, and empirical research about them. This paper finding shows there are two main different arguments about frequent reporting. First, there is evidence that the establishment of mandatory quarterly reporting did not affect on the timeliness of actual earnings (see Butler et al, 2002). They argue that quarterly reporting replaced well-timed voluntary disclosures. Butler et al. (2002) believe that forcing managers to report earnings several time in the year, may push them to make unreasonable decisions. The second argument is that more frequent reporting may persuade additional information compilation activity by analysts and users. However, in spite of some of the conditions stated above, their analysis of price inconsistency in announcement periods gives counter-evidence that increasing in reporting frequency can make financial reports more valuable to investors and the other users.

\section{Acknowledgment}

We thank Prof. McLeay and his colleague Dr. Christodoulou for their valuable comments.

\section{References}

Brown, L., \& Pinello, A. S. (2007). To What Extent Does the Financial Reporting Process Curb Earnings Surprise Games? Journal of Accounting Research, 45(5), 947-981. http://dx.doi.org/10.1111/j.1475-679X.2007.00256.x

Butler, M., Kraft, A., \& Weiss, I. S. (2002). The Effect of Reporting Frequency on the Timeliness of Earnings: The Cases of Voluntary and Mandatory Interim Reports. Working Paper, William E. Simon Graduate School of Business, Rochester, NY.

Cuijpers, R., \& Peek, E. (2010). Reporting Frequency, Information Precision and Private Information Acquisition. Journal of Business Finance and Accounting, 37(1-2), 27-57. http://dx.doi.org/10.1111/j.1468-5957.2009.02180.x

Dargenidou, C., Mcleay, S., \& Raonic, I. (2001). Accruals, Disclosure and the Pricing of Future Earnings in the European Market. Journal of Business Finance \& Accounting, 38(5-6), 473-504. http://dx.doi.org/10.1111/j.1468-5957.2011.02245.x

Dechow, P., Kothari, S. P., \& Watts, R. L. (1998). The Relation between Earnings and Cash Flows. Journal of Accounting \& Economics, 25(2), 131-214. http://dx.doi.org/10.1016/S0165-4101(98)00020-2

Doran, D. T. (2011). Earnings Performance and Interim Reporting. Journal of Applied Business Research, 11(1), 67-72.

Firth, M. (1981). The Relative Information Content of the Release of Financial Results Data by. Journal of Accounting Research, 19(2), 521-529. http://dx.doi.org/10.2307/2490878

Gigler, F., \& Hemmer, T. (1998). On the frequency, quality, and informational role of mandatory financial reports. Journal of Accounting Research, 36, 117-147. http://dx.doi.org/10.2307/2491310

Lunt, M. C. H. (1982). The role of interim accounts and preliminary profit announcements in financial reporting 
in the U.K. Institute of Chartered Accountants of England and Wales, 198.

Mangena, M., \& Pike, R. (2005). The Effect of Audit Committee Shareholding, Financial Expertise and Size on Interim Financial Disclosures. Accounting and Business Research, 35(4), 327-349. http://dx.doi.org/10.1080/00014788.2005.9729998

Mangena, M., \& Tauringana, V. (2007). Corporate Compliance and Non-Mandatory Statements of Best Practice: The Base of the ASB Statements of Interim Results. European Accounting Review, 16(2), 399-427. http://dx.doi.org/10.1080/09638180701391014

Mensah, Y. M., \& Werner, R. H. (2008). The Capital Market Implications of the Frequency of Interim Financial Reporting: an International Analysis. Review of Quantitative Finance and Accounting, 31(1), 71-104. http://dx.doi.org/10.1007/s11156-007-0069-0

McNichols, M., \& Manegold, J. (1983). The Effect of the Information Environment on the Relationship between Financial Disclosure and Security Price Variability. Journal of Accounting and Economics, 5(1), 9-74.

Opong, K. (1995). The Information Content of Interim Financial Reports: UK Evidence. Journal of Business Finance \& Accounting, 22(2), 306-68. http://dx.doi.org/10.1111/j.1468-5957.1995.tb00683.x

Saeed, P. S., Amir, R. (2011). An Examination of the Factors Affecting the Timeliness of Interim Financial Reporting: The Case of Malaysian Listed Companies.

Schiller, U., \& Vegt, M. D. (2010). Interim reporting and Accounting quality.

Yee, K. (2004). Interim Reporting Frequency and Financial Analysts' expenditures. Journal of Business Finance and Accounting, 31(1-2), 167-198. http://dx.doi.org/10.1111/j.0306-686X.2004.00005.x

\section{Notes}

Note 1. The Transparency Directive (TD) was published in the Official Journal of the EU on 31 December 2004, and came into force as a Directive on 20 January 2005, with a 24-month implementation period. The TD was was implemented in the UK on 20 January 2007.

Note 2. IAS 34 determines the minimum content for interim reports and the principles for detection in such reports; for more information see http://www.ifrs.org/NR/rdonlyres/2E15F246-850B-4717-987B-50C21C375EF5/0/IAS34.pdf

Note 3. The relevant Financial Reporting Releases are: 46 FR 12489 (Feb 17, 1981), 50 FR 25215 (June 18, 1985), 50 FR 49533 (Dec 3, 1985), 57 FR 45293 (Oct 1, 1992), 64 FR 73401 (Dec 30, 1999), 73 FR 956 (Jan 4, 2008), 74 FR 18616 (Apr 23, 2009), 76 FR 50120 (Aug 12, 2011).

Note 4. For fully-listed companies, the first set of consolidated accounts which had to be prepared under IFRS was for the first period that commenced on or after $1^{\text {st }}$ January 2005 , i.e. for companies with December year ends, the first IFRS accounts were for the year ended 31st December 2005.

Note 5. In 2006, The International Financial Reporting Interpretations Committee (IFRIC) published an Interpretation IFRIC 10 Interim Financial Reporting and Impairment. The statement shows the clear difference between the requirements of IAS 34 and those in other standards on the detection and reversal in interim financial reports of impairment possible losses on goodwill and convinced financial assets. IFRIC 10 illustrates that any such impairment losses distinguished in an interim report should not be reversed in following interim or annual financial reports.

Note 6. The effective date of the latest (May 2010) amendment to IAS 34 is 1 January 2011.

Note 7. Listed companies were required to issue their interim financial reports within three months of the period-end (before 20 January 2007). The accounting periods starting on or after $20^{\text {th }}$ of January 2007, a semi-annually report must be issued within 60 days of the period end.

Note 8. Appendix B to IAS (34) makes guidance for using the basic recognition and measurement principles to different types of asset, liability, income and expense.

Note 9. Dargenidou C, Mcleay S and Raonic I (2001). argue that how the firm's disclosure performance affect the mix of earnings information reproduced in its current period returns. They focus on explaining current period returns in terms of innovations about current activities and earnings expectations in future. According to their method, the related information is explained by the level of earnings in current and future period after controlling the anticipated level of earnings and future unexpected innovations (in terms of future returns). According to their research, stock returns of the $i$ firm for year $t$ is measured over the twelve-month period, 
ending 90 days after the fiscal year end.

\section{Copyrights}

Copyright for this article is retained by the author(s), with first publication rights granted to the journal.

This is an open-access article distributed under the terms and conditions of the Creative Commons Attribution license (http://creativecommons.org/licenses/by/3.0/). 